(http://linkinghub.elsevier.com/retrieve/pii/S0003267002010292)

DOI: 10.1016/S0003-2670(02)01029-2

(http://dx.doi.org/10.1016/S0003-2670(02)01029-2)

\title{
An assessment of dissolution techniques for the analysis of ceramic samples by plasma spectrometry.
}

\author{
Alexandra Tsolakidou ${ }^{1-2^{*}}$, Jaume Buxeda i Garrigós ${ }^{1}$, Vassilis Kilikoglou ${ }^{2}$
}

Analytica Chimica Acta, 474, 177-188 (2002)

${ }^{*}$ Corresponding author. Tel. 0030-1-6503303; fax: 0030-1-6519430; e-mail:

alexts@ims.demokritos.gr 


\title{
An assessment of dissolution techniques for the analysis of ceramic samples by plasma spectrometry.
}

\author{
Alexandra Tsolakidou ${ }^{1-2^{*}}$, Jaume Buxeda i Garrigós ${ }^{1}$, Vassilis Kilikoglou ${ }^{2}$ \\ 1-ERAUB, Dept. de Prehistòria, Història Antiga i Arqueologia, Universitat de \\ Barcelona, C/ de Baldiri i Reixac, s/n, 08028 Barcelona (Catalonia, Spain) \\ 2- Institute of Materials Science, NCSR “Demokritos”, 15310 Ag. Paraskevi, Attiki,
}

\section{Greece}

\begin{abstract}
In this study, thirteen ceramic samples were subjected to dissolution using three different procedures: a) Acid attack in open PTFE vessels with a mixture of $\mathrm{HF}-\mathrm{HClO}_{4}$ b) Fusion of the sample with lithium metaborate and c) Microwave digestion in PTFE bombs. The samples used in the study had been previously analysed by Neutron Activation Analysis, X-Ray Fluorescence and X-Ray Diffraction and they cover a wide range of ceramics fired in different atmospheres and temperatures as well as different mineralogical and chemical compositions. The effectiveness of each procedure is evaluated in terms of its ability to dissolve the various mineralogical phases of the samples, of the number of elements that can be determined and of the time needed for the whole scheme of analysis to be completed.
\end{abstract}

Keywords: Ceramics, Inductively Coupled Plasma Spectroscopy, acid attack in open beakers, alkali fusion, microwave digestion.

${ }^{*}$ Corresponding author. Tel. 0030-1-6503303; fax: 0030-1-6519430; e-mail:

alexts@ims.demokritos.gr 


\section{Introduction}

Inductively coupled plasma-atomic emission spectrometry has been largely acknowledged and extensively used in the multi-elemental analysis of geological samples $[1,2,3,4]$. More recently, inductively coupled plasma-mass spectrometry is being progressively applied to the analysis of geological materials for the determination of trace amounts of elements $[5,6]$.

The two instruments have the same source, the discharge of which can excite either optical emission or ions. Therefore the sample introduction requirements are common to both techniques. Although a range of sample introduction procedures can be used, the usually preferred method is the liquid introduction. In this way, many samples can be quickly analysed and a large number of elements can be simultaneously determined. A critical, as well as, time-consuming step in the scheme of silicates' analysis is the dissolution of the samples. Very often the digestion of silicate samples is incomplete $[7,8,9,10]$ thus affecting the accuracy and precision of the analysis. All the procedures available for the dissolution of the silicate rocks can be applied on ceramic samples [11]. The most commonly used methods are based on the fusion of the sample or on the dissolution of the sample by acid attack involving the use of hydrofluoric acid.

In the field of Archaeometry, elemental chemical analysis has been widely applied to the study of provenance of archaeological pottery. The method is based on the determination of the highest possible number of major, minor and trace elements in the ceramics under investigation and comparison to ones of known or assumed provenance. Up to date, Neutron Activation Analysis has been the most popular technique in provenance studies, because of its capability to determine simultaneously a large number of elements without sample dissolution. As a result, extensive analytical databanks exist for ceramics, with data available from all over the world and most of the archaeological periods (e.g: www.missouri.edu/ reahn/archdata.htm). $\mathrm{X}$-ray Fluorescence is also a well established technique for provenance studies, which 
has the advantage of determining most of the major elements that exist in ceramics. However, its main disadvantage is that it requires a very large sample in order to determine trace elements. In many cases, in order to obtain the optimum number of elements, both techniques are used, NAA for trace and XRF for major elements. In comparison to NAA and XRF, ICP-OES is relatively new in the field but it is gradually becoming more popular as it combines the determination of major elements with some trace ones $[12,13,14,15]$. However, the measurement of the rare earth elements by ICP-OES in ceramics is quite problematic, since chemical separation is usually needed before the measurement [16], thus increasing the cost and the time needed for the analysis. Additionally, the sensitivity of trace element analysis by ICPOES is influenced by the concentration of calcium and alkali metals $[17,18,19]$ that are main components of pottery. The determination of the rare earth elements has been readily achieved by the introduction of ICP-MS, which has recently been recognised as a very powerful technique for the determination of trace amounts of elements, including rare earth elements, in ceramics [20]. It is apparent that the combination of both ICP OES and MS has a great potential for the determination of a very large suite of elements and for this reason their application on provenance of archaeological ceramics is increasing. The main difficulty to overcome, remains a procedure that could be routinely applied for the rapid and complete dissolution of the sample. Provenance studies of ancient pottery involve the analysis of large numbers of samples, therefore the rapidity of the sample preparation stage is essential.

In the present study, thirteen ceramic samples covering a wide range of chemical compositions and mineralogical characteristics were analysed, using for all of them the three commonest dissolution procedures for silicate materials: acid attack in open PTFE vessels, alkali fusion and microwave digestion in PTFE bombs. The reason that ceramic samples are used and not certified reference materials is that fired ceramic reference materials with certified values for trace elements do not exist. The effectiveness of each procedure is evaluated in terms of the closeness of the results to 
the expected values, in terms of the available number of elements to be determined and in terms of the time needed for the whole scheme of analysis to be completed.

\section{Experimental}

\section{Sample selection}

Ancient pottery in general was manufactured from very different kinds of clays. The selection of the clay depended on the intended function of the produced vessels. Because the use of pottery was very diverse, the chemistry, mineralogy and granulometry of the clays differed to suit the use-related characteristics of the ceramics. Therefore the clays used, contained different amounts of calcium or iron and they originated from diverse kinds of parent rocks (igneous, volcanic or metamorphic), thus bearing different chemical compositions. In this work thirteen samples, representative of different chemical and mineralogical compositions of raw materials were selected so that the effect of the different chemistry and mineralogy on the dissolution of the ceramic could be tested.

In order to investigate the effect of the firing temperature and the kiln atmosphere in the dissolution of pottery, a calcareous clay from Vilafranca de Bonany (Mallorca) was selected from which six briquettes were fabricated. Three of these were fired at $600^{\circ} \mathrm{C}, 850^{\circ} \mathrm{C}$ and $1100^{\circ} \mathrm{C}$ in oxidising atmosphere (sample names: Vilox600, Vilox850 and Vilox1100) and the remaining three briquettes were fired at $600^{\circ} \mathrm{C}$, $850^{\circ} \mathrm{C}$ and $1050^{\circ} \mathrm{C}$ in reducing atmosphere (sample names Vilred600, Vilred850 and Vilred1050). This clay was selected because it is a calcareous clay currently used mixed with other clays for the manufacture of traditional Mallorcan pottery.

For the same reason non-calcareous clay from Pòrtol (Mallorca) was selected as well, and two briquettes were fired at two different temperatures $\left(800^{\circ} \mathrm{C}\right.$ and $\left.1100^{\circ} \mathrm{C}\right)$ in oxidising atmosphere (sample names Portol800 and Portol1100). This is also a clay currently used for the manufacture of cooking pot vessels in Mallorca. 
In order to investigate the effect of the different chemical and mineralogical compositions in the dissolution of the pottery, five archaeological ceramic sherds were selected bearing different chemistry and mineralogy. The samples are:

a) MPY93/26: a Minoan Bronze Age coarse, low-calcareous low fired $\left(<750^{\circ} \mathrm{C}\right)$ ceramic sherd, with a high $\mathrm{Cr}$ content.

b) S-13: a Roman Terra Sigillata from the Abella (Catalonia, Spain) kiln site. It is a fine, over fired, calcareous sherd, almost molten because of the high firing $\left(>1100^{\circ} \mathrm{C}\right)$ temperature.

c) CS-26: a Late Roman Cooking Ware from Pantelleria (Italy). It is coarse, low calcareous and high fired $\left(>950^{\circ}\right)$ ceramic sherd, with a high $\mathrm{Zr}$ and $\mathrm{Nb}$ content.

d) 120-B: a contemporary traditional cooking ware produced at the village of Pereruela (Spain). It is a low calcareous high fired $\left(1000^{\circ} \mathrm{C}\right)$ sherd, with a high monazite content (reflected in the high content in REE).

e) GE-076: a Late Roman Jerash Bowl possibly produced at Jerash (Jordan). It is a low calcareous high fired $\left(1000^{\circ} \mathrm{C}\right)$ sherd with a relatively high Ti content

The estimation of the firing temperature of the ancient ceramics was carried out by Scanning Electron Microscopy and X-Ray Diffraction [21]. A summary of the characteristics of the selected samples is given in Table 1.

\section{Chemical analysis of the samples}

\section{A. Neutron Activation Analysis}

A piece of each sherd was cleaned by drilling off the surface with a tungsten carbide drill-bit and then finely powdered in an agate mortar. Ceramic samples and standards weighing about $130 \mathrm{mg}$ each, were placed into polyethylene vials, heatsealed and irradiated for $30 \mathrm{~min}$ at the "Demokritos" swimming pool reactor, in a thermal neutron flux of about $3 \cdot 10^{13} \mathrm{n} \cdot \mathrm{cm}^{-2} \cdot \mathrm{s}^{-1}$. The samples were irradiated in batches of ten (each batch contained eight samples and two standards). The International Atomic Energy Agency Certified Reference Material, SOIL-7 was employed as a standard. After irradiation, samples and standards were counted twice. The first count 
took place after a cooling period of eight days, for the determination of the short-lived radionuclides ( $\mathrm{Na}, \mathrm{Ca}, \mathrm{La}, \mathrm{Sm}, \mathrm{Yb}, \mathrm{Lu}, \mathrm{U})$ and the second count two weeks later, for the determination of the long-lived radionuclides $(\mathrm{Sc}, \mathrm{Cr}, \mathrm{Fe}, \mathrm{Co}, \mathrm{Rb}, \mathrm{Cs}, \mathrm{Ce}, \mathrm{Eu}, \mathrm{Tb}$, Th). A Ge $\gamma$-detector covering the energy range of $80-1600 \mathrm{keV}$ was used for the measurements. For the determination of the precision and accuracy of the technique ten replicates of the Montana soil-certified material (NIST SRM 2711) were prepared and measured separately. The values for the accuracy and the precision as well as the detection limits of the specific neutron activation establishment are shown in Table 2. The values for the accuracy of elements with non-certified values are given for information purposes.

\section{B. X-Ray Fluorescence Analysis}

The analysis by X-Ray Fluorescence was performed at the Scientific-Technical Services of the University of Barcelona. For the determination of the major and minor glassy pills were prepared by mixing $0.3 \mathrm{~g}$ of dry sample with $5.7 \mathrm{~g}$ of $\mathrm{LiBO}_{4}$ (dilution 1/20). The mixture was fused to a glassy pill of a diameter of $30 \mathrm{~mm}$, at a temperature of $1150^{\circ} \mathrm{C}$ using a high frequency induction furnace Perl'X-2. Every sample was prepared in duplicates. For the determination of the trace elements the sample was prepared as a powder pellet by mixing $5 \mathrm{~g}$ of dry sample with $2 \mathrm{ml}$ of a solution of a synthetic resin (Elvacite 2044, 20\% in acetone). The mixture was homogenised until dryness, in an agate mortar. The powder pellets were made by adding the mixture in an aluminium capsule containing boric acid and by pressing the capsule in a Herzog press under a pressure of $200 \mathrm{kN}$ for $60 \mathrm{~s}$.

The fluorescence intensity was measured with a Philips PW 2400 wavelength dispersive spectrometer having a $\mathrm{Rh}$ excitation source and the quantitative analysis of the elements was performed with a calibration line made of 56 International Geological Reference Materials. The elements determined by XRF were: $\mathrm{Na}_{2} \mathrm{O}, \mathrm{MgO}$, $\mathrm{Al}_{2} \mathrm{O}_{3}, \mathrm{SiO}_{2}, \mathrm{~K}_{2} \mathrm{O}, \mathrm{CaO}, \mathrm{TiO}_{2}, \mathrm{MnO}, \mathrm{Fe}_{2} \mathrm{O}_{3}$ (as total $\mathrm{Fe}$ ), Ni, Rb, Sr, Zr, Ba, Th. The lower limits of the concentration ranges of the elements that were determined by XRF 
according to the calibration done with the standards mentioned above are shown in Table 3. For the determination of the precision of the technique 10 replicates of the Montana soil-certified material (NIST SRM 2711) were prepared and measured separately. The values are shown in Table 3 . The values for the accuracy of the elements with non-certified values are given for information purposes.

The chemical composition determined by Neutron Activation Analysis and XRay Fluorescence for all the above-mentioned samples is given in Table 4 (values for $\mathrm{Ni}, \mathrm{Sr}, \mathrm{Zr}$ and $\mathrm{Ba}$ for sample MPY93/26 were not determined because the sample was not analysed for trace elements by XRF). The complete chemical data-set was produced by joining the NAA and XRF data. For the common elements $\mathrm{CaO}, \mathrm{Fe}_{2} \mathrm{O}_{3}$ and $\mathrm{Rb}$ concentrations determined by XRF were selected, while for $\mathrm{Ce}$, Co and Th the NAA results were taken. This was decided after taking into account the analytical performance of both techniques for the particular elements as it is discussed later in the text. The chemical analysis for the calcareous and non-calcareous briquettes was performed on the briquettes fired at $950^{\circ} \mathrm{C}$ in oxidising atmosphere.

The NAA and XRF set-ups used for the analysis of the samples in the present study as well as their analytical characteristics are described in more detail by Hein et al [22].

\section{X-Ray Diffraction}

The mineralogical composition of the samples was determined by X-Ray Diffraction. The measurements were performed in a Siemens D-500 Diffractometer, working with a $\mathrm{Cu} \mathrm{K}-\alpha$ Radiation $(\lambda=1.5406 \AA)$ and monochromator graphite in the diffracted beam at $1.2 \mathrm{~kW}(40 \mathrm{kV}, 30 \mathrm{~mA})$. Spectra were taken from 4 to $70^{\circ} 2 \theta$ at $1^{0} 2 \theta / \mathrm{min}$.

A description of the mineralogical composition of the samples is given in Table 1. The mineralogical composition of the experimental briquettes is presented in three columns, in the first of which the non-plastic inclusions are given in the second the clay minerals and in the third the firing phases. The firing temperatures of the 
archaeological samples were determined by a combination of X-Ray Diffraction and Scanning Electron Microscopy [21].

\section{Methods:}

\section{A. Dissolution in open PTFE vessels}

Acid digestion with $\mathrm{HF}$ is usually used in combination with a second acid $\left(\mathrm{HNO}_{3}\right.$, $\mathrm{H}_{2} \mathrm{SO}_{4}$ or more commonly $\mathrm{HClO}_{4}$ ) to digest silicate geological materials [8, 23]. When silicon is not to be determined the digestion is performed in open vessels. During this procedure silicon is lost in the form of its volatile tetra-fluoride and the resulting solution contains a small amount of total dissolved solids, since silicon is usually the most abundant element in silicate samples. In this way more concentrated solutions can be used in order to determine the trace elements. In one single preparation all the major elements except silicon can be determined as well as many of the trace elements.

In the tests performed in the present study approximately $0.15 \mathrm{~g}$ of exactly weighted dry sample were placed in a PTFE beaker in which $5 \mathrm{ml}$ of $\mathrm{HNO}_{3}(65 \%)$ and $5 \mathrm{ml}$ of de-ionised water - the water used for all the procedures was de-ionised and purified with a mixed resin and filters by Milli- $Q^{\circledR}$ water system (Millipore)- were added and the beaker was heated in a sand bath for $1 \mathrm{~h}$ with reflux. The beaker was cooled and $2 \mathrm{ml}$ of $\mathrm{HClO}_{4}$ together with $10 \mathrm{ml}$ of $\mathrm{HF}$ were added and the solution was left covered for at least $12 \mathrm{~h}$ at room temperature. Afterwards, the beaker was uncovered and the solution was evaporated almost to dryness. The addition of $\mathrm{HClO}_{4}$ and $\mathrm{HF}$ and the evaporation steps were repeated until all $\mathrm{SiO}_{2}$ was removed. After all $\mathrm{SiO}_{2}$ had been removed, $5 \mathrm{ml}$ of $\mathrm{HClO}_{4}$ were added and evaporated to dryness. At the final step the beaker was cooled, and $2.5 \mathrm{ml}$ of $\mathrm{HNO}_{3}$ together with $2.5 \mathrm{ml}$ of deionised water were added and heated with a reflux in a sand bath until total salt dissolution. Finally the beaker was cooled and its content was diluted with de-ionised water in a volumetric flask up to $25 \mathrm{ml}$. All samples were dissolved in duplicates and in some cases, when problems encountered, in triplicates. The procedure was 
modified in cases of incomplete dissolution of the first replicate and the modifications are mentioned in the results and discussion section.

Before the introduction in the instrument the solutions were diluted 10 times for the ICP-MS analysis and 5 times for the ICP-OES analysis.

\section{B. Dissolution by alkali fusion}

Major element analysis of silicates, including the analysis of silicon, is usually performed after the digestion of the sample by fusion. Several fluxes had been used in the past mainly sodium carbonate and sodium hydroxide but because they exclude the possibility of the determination of sodium, the fusion using lithium metaborate as a flux finally prevailed $[24,25]$. The fusion using this flux became popular in the dissolution of silicates for the analysis by ICPS [26]. This procedure is effective for the dissolution of all major rock-forming silicates as well as many accessory minerals $[27,28]$. Silicon is retained in the solution so all the majors can be determined from one preparation. The level of the total dissolved solids in the resultant solution is high since the flux-sample ratio is kept between 5:2 and 7:1 [25]. This creates problems in the nebulisation system of the instrument since it clogs the nebuliser. In order to minimise the signal drift and to optimise the precision during the analysis by ICPS, the solutions should contain a total dissolved solids amount of 1-2\% for ICP-OES and $0.1-0.2 \%$ for ICP-MS. This requirement restricts the number of the trace elements that can be determined since the solutions are subject to high dilutions.

In the present study, to overcome the problem of the high dilutions that reduce the number of the trace elements that can be determined, some trials were attempted for the use of a lower flux-sample ratio and finally the ratio used was 2:1.

Approximately $0.1 \mathrm{~g}$ of exactly weighted dry sample were placed in a platinum crucible. The flux was added double the quantity of the sample and the crucible was inserted in a furnace where it was fused at $1100^{\circ} \mathrm{C}$. After the crucible was removed from the furnace, it was cooled and $3 \mathrm{ml}$ of $\mathrm{HNO}_{3}(65 \%)$ together with $3 \mathrm{ml}$ of deionized water were added and it was then heated with stirring until total dissolution of 
its content. At the final step, its content was diluted with de-ionized water up to $100 \mathrm{ml}$.

Before the introduction in the instrument the solutions were diluted 10 times both for the ICP-MS and the ICP-OES

\section{Microwave digestion}

The method of dissolving silicate materials by microwave digestion has been introduced and tested lately, and the outcome has been encouraging because the dissolution could be achieved in a relatively short time with a satisfying accuracy [7, $9,29]$. The procedure proved to be effective in the extraction of numerous elements from soils and sediments [6] as well as in dissolving minerals resistant to acid attack in open beakers, because of the high temperature and the high pressure attained. However, for the total dissolution of geological samples the final steps of the procedure usually involved the evaporation of the content of the digestion vessels to dryness so that silicon is lost and the addition of more $\mathrm{HClO}_{4}$ and evaporation to dryness for the removal of the fluoride ions $[7,9]$. This way the procedure resembles a lot the procedure of the acid attack in open beakers.

In the present study, to differentiate the procedure from that in open beakers, the approach was to use the microwave digestion for the total dissolution of the ceramic samples avoiding the last steps of evaporation, so that $\mathrm{Si}$ could also be determined and the time of the procedure would decrease.

Approximately $0.1 \mathrm{~g}$ of exactly weighted dry sample were placed in a PTFE bomb, where $3 \mathrm{ml} \mathrm{HNO}_{3}(65 \%)$ and $10 \mathrm{ml} \mathrm{HF}(48 \%)$ were added. The bomb was closed and inserted in a laboratory microwave oven (Microwave oven program: 6min at $600 \mathrm{~W}$, $1 \mathrm{~min}$ at $0 \mathrm{~W}, 5 \mathrm{~min}$ at $400 \mathrm{~W}, 6 \mathrm{~min}$ at $600 \mathrm{~W}, 2 \mathrm{~min}$ at $0 \mathrm{~W}, 5 \mathrm{~min}$ ventilation). When the program was over the bombs were cooled in a wind current and they were opened. To neutralize the remaining $\mathrm{HF}, 2.5 \mathrm{~g}$ of $\mathrm{H}_{3} \mathrm{BO}_{3}$ were added in each bomb and after they were closed, they were reinserted in the microwave oven [30] (Microwave oven program: $3 \mathrm{~min}$ at $250 \mathrm{~W}, 2 \mathrm{~min}$ at $0 \mathrm{~W}, 3 \mathrm{~min}$ at $400 \mathrm{~W}, 3 \mathrm{~min}$ at $600 \mathrm{~W}$ and $2 \mathrm{~min}$ 
ventilation). At the final step the bombs were cooled and their contents were diluted up to $50 \mathrm{ml}$ with de-ionized water.

Before the introduction in the instrument the solutions were diluted 50 times both for ICP-MS and ICP-OES.

\section{Instruments and calibration:}

The measurements for ICP-OES were performed by the Thermo Jarrell Ash spectrometer (simultaneous and sequential), with a $27.12 \mathrm{MHz}$ RF-generator and working power between $750-1750 \mathrm{~W}$.

The calibration of the instrument was carried out using $1 \mathrm{M} \mathrm{HNO}_{3}$ as a blank solution and four multi-element standard solutions. The multi-element standard solutions contained all the elements determined by ICP-OES ( $\mathrm{Na}, \mathrm{Mg}, \mathrm{Al}, \mathrm{K}, \mathrm{Ca}, \mathrm{Sc}$ Ti, Mn, Fe, Ni, Sr, Ba). Si was also determined by ICP-OES in the solutions derived after the alkali fusion and the microwave digestion. The four standard multi-element solutions were prepared by diluting a concentrate multi-element standard solution in $1 \mathrm{M} \mathrm{HNO}_{3}$. To correct for long-term machine drift these solutions were analysed after every 10 samples. For the preparation of the concentrate standard solution singleelement CPI International standards were used.

The measurements by ICP-MS were performed with the ICP-MS Perkin-Elmer model Elan-6000 spectrometer, with a cross flow nebulizer, a 40MHz RF-generator and a working power between $600-1600 \mathrm{~W}$.

The instrument was calibrated with a $1 \mathrm{M} \mathrm{HNO}_{3}$ solution used as a blank and four multi-element standard solutions in a $1 \mathrm{M} \mathrm{HNO}_{3}$ matrix, that contained $\mathrm{Sc}, \mathrm{Ti}, \mathrm{Cr}, \mathrm{Mn}$, Co, Ni, Rb, Sr, Zr, Cs, Ba, La, Ce, Sm, Eu, Tb, Yb, Lu, Th and U. For the preparation of the multi-element solution single-element CPI International standard solutions of $1000 \mathrm{ppm}$ concentration were used. Internal standardisation was employed to correct for instrumental drift and matrix induced interferences. More specifically internal standards of $\mathrm{Cl}$ and $\mathrm{Ca}$ were used to correct for interferences the elements $\mathrm{Cr}$, $\mathrm{Co}$ and Ni. Internal standard of Rh was used to correct for the drift in signal intensity. 
For the determination of the precision and accuracy of the ICP-OES and ICP-MS set-ups 10 replicates of the SRM 2711 (Montana soil-certified material) provided by the NIST were prepared, by dissolution in open PTFE vessels, and measured separately. The values for the accuracy and the precision of the technique together with the detection limits and the experimental errors of the specific setup are shown in Tables 5 and 6 . The accuracy values for the elements with non-certified values are given for information purposes.

The analytical characteristics of both ICP-OES and ICP-MS set-ups used in the present work are described in detail by Hein et al [22]

\section{Results and discussion}

As mentioned in the introduction, Neutron Activation Analysis and X-Ray Fluorescence analysis are very well established and routinely used in the chemical characterisation of pottery, especially for provenance studies. The precision and accuracy of the specific set-ups used in the present study were tested and presented in Tables 2, 3, 5 and 6. In Table 2 the values for the precision for the NAA set-up are given. As it can be seen the precision, expressed as the percent standard deviation, was below $6 \%$ except for $\mathrm{U}, \mathrm{Ca}$ and $\mathrm{Tb}$ for which it is slightly higher. The accuracy given as the $\%$ deviation from the certified values is at the range of $9 \%$ or lower, with the exceptions of $\mathrm{Ce}, \mathrm{Cr}, \mathrm{U}$ and $\mathrm{Yb}$ for which the reported values by NIST are not certified anyway. The analysis by XRF gave values with high precision for the majority of the elements (less than 5\%) with the exception of Ni (Table 3). The accuracy is usually around $10 \%$, with the exceptions of $\mathrm{Na}_{2} \mathrm{O}$ and $\mathrm{Ni}$. Both the precision and accuracy values for the analysis by ICP-OES are at the order of 5\% (Table 5). The same is valid for the analysis by ICP-MS (Table 6) with the exception of $\mathrm{Cr}$. The relatively bad values for the measurement of $\mathrm{Cr}$ are due to the dissolution procedure used for the preparation of the SRM 2711. The solutions were prepared by 
acid attack in open beakers during which the volatile fluoride of the element is formed thus affecting the precision and accuracy of the analysis.

Theoretically, in order to assess the effectiveness of the dissolution procedures on ceramics, certified reference materials should have been used. However, as it has already been mentioned, fired ceramic reference materials with certified values for trace elements do not exist. Therefore, the ceramic samples used in the present study are either clays fired to ceramics or ancient ceramics, the composition of which is determined by NAA and XRF. Because of the extensive use of these techniques in the chemical characterisation of pottery and after the set-ups used in the specific study had been tested in terms of their analytical performance, the values obtained by them for the samples under study, are considered as known values and the values obtained by ICPS after the dissolution of the samples are compared to those known values. For the common elements determined both by ICP-OES and ICP-MS ( $\mathrm{Sc}, \mathrm{Ti}, \mathrm{Mn}, \mathrm{Ni}, \mathrm{Sr}$, and $\mathrm{Ba}$ ) the ICP-OES values of $\mathrm{Sc}, \mathrm{Ti}, \mathrm{Mn}, \mathrm{Sr}$ and $\mathrm{Ba}$ and the ICP-MS values of $\mathrm{Ni}$ have been considered.

The effectiveness of each dissolution procedure was assessed by the recovery yield of each sample to the known values. In the figures below, the recovery yields from the three different preparation procedures are presented, are given within a range of \pm 20 from the known value, indicated by two lines. This range was chosen so that the deviations of the results due to the probable experimental errors and the deviations from the real values that are unknown are also included. Furthermore, a foregoing standardisation study between the laboratories where the ICPS, XRF and NAA analyses were performed proved that the differences among the values obtained by the three techniques for the common elements determined are within a $\pm 20 \%$ range [22].

\section{Acid attack in open beakers}

In Figure 1 the recoveries from the acid attack in open beakers for the archaeological samples (MPY93/26, S-13, 120-B, CS-26 and GE-076) are given. As it can be seen the majority of the elements were recovered well with all the values lying 
within the range of $100 \pm 20 \%$. Zirconium as might be expected gives low recovery values for the majority of the samples. It is known that the mineral phases containing this element are particularly insoluble in concentrated acids even after days of digestion in considerably high temperatures and pressures [31]. As a result, most of the $\mathrm{Zr}$ content in the ceramic sherds cannot be taken into solution by the $\mathrm{HF} / \mathrm{HClO}_{4}$ attack [32].

Another element with a low recovery value is $\mathrm{Ni}$ in the sample CS-26. This is probably due to the very low Ni content in the sample, which is actually the lowest of all the samples (4ppm) and very close to the detection limit of the ICP-OES set-up by which it was determined (Table 5).

Chromium was recovered reasonably well (all the values are within the $100 \pm 20 \%$ range) from the samples with a relatively low content. The lowest $\mathrm{Cr}$ recovery value (78\%) concerns sample MPY93/26 that exhibits a very high $\mathrm{Cr}$ content (almost $1000 \mathrm{ppm}$ ) the highest of all the samples and is suspected to contain chromite (due to its ultrabasic mineral content that was determined by thin section petrological examination), which is known to be resistant to acid attack.

Though the recoveries for most of the rare earth elements determined ( $\mathrm{La}, \mathrm{Ce}, \mathrm{Nd}$, $\mathrm{Sm}, \mathrm{Eu}, \mathrm{Tb})$ were excellent (88\%-106\%) the recoveries yielded for $\mathrm{Yb}$ and $\mathrm{Lu}$ were low $(50 \%-81 \%)$ for the sample Ge-076. The phenomenon of the low recovery for $\mathrm{Yb}$ and $\mathrm{Lu}$ after acid digestion has been observed before and it was attributed to the very low solubility of the $\mathrm{REEF}_{3}$ species, which is controlled by ionic radius. The recovery for the trivalent group of the REE declines with the decrease in ion radius. Additionally, in the presence of major elements that can act as carriers, the $\mathrm{REE}^{3+}$ can be trapped into the $\mathrm{Al}^{3+}$ site or they can form $\mathrm{MgREEF}_{5}$ (or $\mathrm{CaREEF}_{5}$ ) species, which precipitate [33].

The recovery of Th is very good for all the samples. The recovery of $U$ is low for 3 of the samples (MPY93/26, CS-26, GE-076). The low recovery of $U$ is probably due 
to trapping of the element in divalent cation sites of major elements that form fluorides that precipitate [33].

The picture for the clay samples (Figure 2) is quite similar to the one of the archaeological samples. The low recoveries concern again the elements $\mathrm{Zr}, \mathrm{Yb}, \mathrm{Lu}$ and U. In the case of the clay samples of Figure 2 the low recoveries for the above mentioned elements are more systematic. In fact, the samples in this graph were more difficult to dissolve than the archaeological samples and produced nebulous solutions after repeated evaporations. Even after evaporating them 3 times with $5 \mathrm{ml} \mathrm{HClO}_{4}$ the resultant solutions were still nebulous though better than after one evaporation with $\mathrm{HClO}_{4}$.

The main difference between the two figures is that in Figure 2 the Co value is missing. As mentioned above the known values for the clay samples correspond to the briquettes fired at $950^{\circ}$ both for the calcareous and the non-calcareous clay. Before the dissolution all the briquettes were powdered in a tungsten carbide cell that induces Co and $\mathrm{W}$ contamination to the powdered sample. Because the value of Co was suspected to be contaminated and was not measured in the clay samples before the dissolution, this element was not included in the recovery diagrams of the clay samples for all the dissolution procedures.

\section{Alkali fusion}

In Figure 3, the recoveries of the archaeological samples after the dissolution by fusion with lithium metaborate, are shown. The recoveries for all the elements lie within the range $100 \% \pm 20 \%$. Exception is the $\mathrm{Ni}$ value for sample $120 \mathrm{~B}$. The $\mathrm{Rb}$ recovery is relatively high for the sample MPY93/26 and the Cs recovery yield is low for the sample CS-26. The recovery of U for the samples CS-26 and GE-076 is low.

In general the dissolution by alkali fusion is a very effective procedure for dissolving rocks and mineral phases that are resistant to acid attack. Nevertheless, for the analysis of the resultant solutions by ICPS there exists a prerequisite that makes the analysis of these solutions problematic. The total dissolved solid content (TDS) 
should be less than $2 \%$. This is usually not feasible for this method since the flux (lithium metaborate) is used in a proportion 7-10 times the weight of the sample in order to achieve complete dissolution. In order to avoid this problem in this work, some preliminary tests were performed with variable flux to sample proportions. The flux to sample ratios examined here, were 4:1, 3:1 and 2:1 It was found in these tests, that a flux to sample ratio of 2:1 would be enough to completely dissolve most of the samples and it was the ratio used in the experiments. In this way the TDS content would be low and the problems of clogging and matrix effects would be avoided. Additionally, the solutions would not need many dilutions so they would be concentrated enough for the traces to be determined.

The low recoveries of some of the elements for the above mentioned samples are most probably due to the low flux to sample ratio. It seems that the flux quantity, for the specific samples, was not enough to achieve complete dissolution.

The observations are very similar for the recoveries of the clay samples shown in Figure 4. The low recoveries of some of the elements are most probably the result of the insufficient flux to sample proportion.

In general the results in the solutions after the dissolution by fusion were very good for both the major and the trace elements and for all kinds of samples.

\section{Microwave digestion}

In Figure 5 the recoveries of the elements of the archaeological samples are shown after the dissolution by microwave digestion. As it can be seen problems were encountered in the determination of both major and trace elements.

A similarly bad picture is seen in Figure 6 where the recoveries of the clay samples are given, after their dissolution by microwave digestion.

The bad recovery values in both graphs can be attributed either to the incomplete dissolution of phases resistant to acid attack or to the precipitation of elements that form insoluble fluorides. Another aspect that should be taken into account is the possibility of facing matrix effects. 
Many of the solutions after the completion of the procedure were nebulous and they became transparent only after the complementary addition of $\mathrm{H}_{3} \mathrm{BO}_{3}$.

In both Figure 5 and Figure 6 what strikes the attention is the low recovery of many of the major elements. Nevertheless, the recovery of $\mathrm{Ca}$ is good though one would expect that it would show the largest discrepancy owing to the insoluble nature of calcium fluoride. Because the majority of the samples under examination contained a low Ca content this discrepancy is not observed. The sample S-13 with the highest $\mathrm{Ca}$ content shows the highest discrepancy. In general, the phenomenon of the low recovery of the major elements is due to the formation of insoluble fluorides of these elements that precipitate. The addition of $2.5 \mathrm{~g}$ of $\mathrm{H}_{3} \mathrm{BO}_{3}$ proved not to be enough for many of the samples in order to bind the remaining HF after the digestion. Therefore, in these cases, more boric acid was added in the solutions that were heated with stirring. Although these solutions became transparent and the major elements were determined with good recoveries, the determination of the trace elements was still problematic. While the further addition of $\mathrm{H}_{3} \mathrm{BO}_{3}$ helped in dissolving the major element fluorides resulting in good recoveries for these determinations by ICP-OES, it created many matrix effects, because of the high TDS content of the resultant solutions, for the determinations of the trace elements by ICP-MS.

Matrix effects create problems in the elemental determinations especially in ICPMS $[34,35,36]$. Many studies have been carried out on these effects $[37,38]$ and they report that several factors can provoke suppression or enhancement of the analyte signal $[31,38]$. More specifically, it has been reported that especially calcium and the alkali metals [39] can cause severe enhancements of the analyte signals that also depend on the operating conditions of the instrument. These enhancements can be removed only after about two hours of running alkali free solutions.

Probably, such enhancements were provoked by matrix effects in the solutions resulted after the microwave digestion and the further addition of boric acid, giving high recovery values for some elements. 
It needs to be taken into account that the studies mentioned above were performed in solutions possessing a matrix much simpler than that of a ceramic sample. The complex matrix of a pottery sample containing such an excess of major and incompatible trace elements could potentially be responsible for severe matrix effects that should be further studied.

\section{Conclusions}

The scope of this study was to compare different procedures for dissolving ceramic samples and to examine the effect that the composition and firing temperature of the sample would have on its dissolution. As far as the effect of the firing temperature on the dissolution of ceramic samples is concerned, it seems that it is not significant. The problems encountered concern rather specific elements than specific samples. Especially in the case of the archaeological samples, they were all (low and high fired) well dissolved either by acid attack in open vessels or by alkali fusion. Additionally, neither the Ca content of the sample nor the firing atmosphere seems to affect its dissolution.

The acid attack in open beakers achieved good results for all the samples both low and high-fired. Nevertheless, it is a very time consuming procedure and the results are not guaranteed. Especially when there are phases that are resistant to acid attack (Zr, Cr) the complete dissolution of the sample cannot be achieved. Furthermore problems are encountered in the determination of the rare earth elements the recoveries of which depend on their ionic radius and the content of the sample in major elements. Additionally, Si cannot be determined since it is lost during the evaporations.

The fusion with lithium metaborate gave very good results for all types of samples. All the rare earth elements that are the most important when provenance studies of pottery are undertaken, were determined very well. The problems encountered in the determination of some elements in specific samples are most probably due to incomplete dissolution of these samples because a very low quantity of flux was used 
so that the matrix of the resultant solution would be simpler. Using a slightly higher amount of flux ( 3 times instead of 2 times the sample weight) and a higher heating time could overcome this problem. The additional advantage is that all the major and trace elements can be determined in one preparation. In the tests presented above the dissolution by fusion proved to be independent to the mineralogical and chemical composition of the ceramic samples since the recovery values were satisfying for all the samples and all the elements. In general, in the literature studies on ancient pottery up to now, alkali fusion is the preferred dissolution method mainly for the determination of the major elements. In the present study, it became clear that alkali fusion is the most effective of the three procedures at least as far as pottery samples are concerned and gives the possibility, after some modifications in the flux to sample ratio, for the determination of major and trace elements. Furthermore, the time needed for this procedure to be completed is much less than the time needed for the acid attack in open vessels and comparable to that of the microwave digestion.

The dissolution of the ceramic samples with the microwave digestion did not give good results. Phases resistant to acid attack did not dissolve completely. The resultant solution after the addition of boric acid possessed a very heavy matrix and this created many problems in the determinations. A possible solution to the problem would be the addition in the beginning of the digestion of a smaller quantity of HF that would require the addition of less amounts of boric acid at the end. Additionally, higher dilutions after the completion of the digestion might resolve the problem. Otherwise, for the procedure to be effective, the last steps of it should be the evaporation to dryness of the excess of $\mathrm{HF}$ and then the addition of $\mathrm{HClO}_{4}$ so that the fluoride ions would be removed. Thus, no addition of boric acid would be required and silicon would be lost. However, the procedure this way would be very similar to that of the acid attack in open beakers and equally time-consuming so there would be no real difference between them. 
Acknowledgments

The authors would like to thank the GEOPRO Research Network funded by DGXII of the European Commission, under the Training and Mobility of Researchers Network Program (Contract number ERBFMRX-CT98-0165) that supported this study financially. Dr. M.A. Cau Ontiveros provided us with the sample CS-26. We are also indebted to the personnel of the Scientific-Technical Services (University of Barcelona) for their technical support.

\section{References}

[1] Walsh, J.N. and Howie, R.A., Miner. Magaz., 1980, 43, 967

[2] Bakhtar, D., Bradford, G.R. and Lund, L., Analyst, 1989, 114, 901

[3] Marshall, J., Carol, J., Crighton, J.S., Bernard C.L.R., J. Anal. At. Spectrom., 1994, 9, 319R.

[4] Fairman B., Hinds M.W., Nelms, S.M., Penny D.M., Goodall, P., J. Anal. Atom. Spectrom., 1998, 13, 233R.

[5] Jarvis, K.E., J. Anal. At. Spectrom., 1989, 4, 563

[6] Bettinelli, M., Baffi, C., Beone, G.M. and Spezia, S., At. Spectrosc., 2000, 21(2), 60

[7] Diegor, W., Longerich, H., Abrajano, T., Horn, I., Anal. Chim. Acta, 2001, 431, 195.

[8] Langmyhr, F.J and Sveen S., Anal. Chim. Acta, 1965, 32, 1

[9] Totland, M., Jarvis, I., Jarvis K.E., Chemical Geol., 1992, 95, 35

[10] M. Totland, I. Jarvis, K.E. Jarvis, Chem. Geol., 1995, 124, 21.

[11] Bennett, H., Analyst, 1977, 102, 153

[12] Argyropoulos, V., Archaeometry, 1995, 37(2), 271

[13] Paama, L., Peramaki, P., Lajunen, L.H.J., Piiri, L., At. Spectrosc., 1995, 16, 248

[14] Paama, L., Pitk@nen, I., PerMmMki, P., Talanta, 2000, 51, 349 
[15] Bruno, P., Caselli, M., Curri, M.L., Genga, A., Striccoli, R., Traini, A., Anal. Chim. Acta, 2000, 410, 193

[16] Weis, D., Paukert T., and Rubeska, I., J. Anal Atom. Spectrom., 1990, 5., 371.

[17] Ramsey M.H. and Thompson M., J. Anal. Atom. Spectrom., 1986, 1, 185

[18] Dubuisson C., Poussel E., and Mermet J.M., J. Anal. Atom. Spectrom., 1997, 12, 281.

[19] Brener, I.B., Zischka M., Maichin B. and Knap G., J. Anal. Atom. Spectrom., 1998, 13, 1257

[20] Holmes, L.J., Robinson, V.J., Makinson, P.R., Livens F.R., The Sc. of the Tot. Env., 1995, 173/174, 345

[21] Buxeda I Garrigos, J., Kilikoglou V. and Day P.M., Archaeometry, 43(3), 2001, 349

[22] Hein, A., Tsolakidou, A., Iliopoulos, I., Mommsen, H., Buxeda i Garrigos, J., Montana, G., Kilikoglou, V., Analyst (in press).

[23] Headridge, J.B, CRC Critical Reviews in Analytical Chemistry, January 1972.

[24] Van Loon, J.C. and Parissis, C.M., Analyst, 1969, 94, 1057

[25] Ingamells, C.O., Anal. Chim. Acta, 1970, 52, 323

[26] Walsh, J.N., Spectrochim. Acta, 1979, 35B, 107.

[27] Cremer, M. and Schlocker, J., Am. Miner., 1976, 61, 318.

[28] Carbonell, V., Sands, A., Salvador A., de la Guardia M., J. Anal. At. Spectrom., $1991,6,233$

[29] Bettinelli, M., Beone, G.M., Spezia, S., Baffi, C., Anal. Chim. Acta, 2000, 424, 289.

[30] Price, W.J., Whiteside, P.J., Analyst 1977, 102, 664

[31] Jarvis, K.E., Chemical Geol., 1990, 83, 89

[32] Thompson, M., Walsh, J.N., Handbook of Inductively Coupled Plasma Spectrometry, eds. Chapman and Hall, New York., 1989, pp 120

[33] Yokoyama, T., Makishima, A., Nakamura E., Chemical Geol., 1999, 157, 175 
[34] Vaughan, M.A., Horlick, G., and S.H. Tan, J. Anal. At. Spectrom., 1987, 2, 765

[35] Tan S.H. and Horlick G., J. Anal. At. Spectrom., 1987, 2, 745

[36] Ting B.T.G., and Janghorbani, M., J. Anal. At. Spectrom. 1988, 3, 325

[37] Thompson, M. and Ramsey, M.H., Analyst, 1985, 110, 1413.

[38] Gregoire, C. D., Spectrochim. Acta, 1987, 42B, 895

[39] Beauchemin, D., McLaren, J.W. and Berman, S.S., Spectrochim. Acta, 1987, 42B, 467 


\begin{tabular}{|c|c|c|c|c|}
\hline Sample & Characteristics & \multicolumn{3}{|c|}{ Mineralogical Composition (XRD) } \\
\hline Vilred600 & $\begin{array}{l}\text { Calcareous clay fired at } \\
600^{\circ} \mathrm{C} \text { in reducing } \\
\text { atmosphere }\end{array}$ & $\begin{array}{l}\text { Quartz } \\
\text { Dolomite } \\
\text { Calcite } \\
\text { Plagioclase } \\
\text { feldspar } \\
\text { Hematite }\end{array}$ & \begin{tabular}{l|} 
Clay \\
minerals \\
(illite/ \\
muscovite \\
and chlorite)
\end{tabular} & \\
\hline Vilred850 & $\begin{array}{l}\text { Calcareous clay fired at } \\
850^{\circ} \mathrm{C} \text { in reducing } \\
\text { atmosphere }\end{array}$ & $\begin{array}{l}\text { Quartz } \\
\text { Plagioclase } \\
\text { feldspar }\end{array}$ & $\begin{array}{l}\text { Clay } \\
\text { Minerals } \\
\text { (illite/ } \\
\text { muscovite }\end{array}$ & $\begin{array}{l}\text { K-feldspars } \\
\text { Gehlenite } \\
\text { Pyroxenes } \\
\text { Iron Spinel }\end{array}$ \\
\hline Vilred1050 & $\begin{array}{l}\text { Calcareous clay fired at } \\
1050^{\circ} \mathrm{C} \text { in reducing } \\
\text { atmosphere }\end{array}$ & $\begin{array}{l}\text { Quartz } \\
\text { Plagioclase } \\
\text { feldspar }\end{array}$ & & $\begin{array}{l}\text { K-feldspars } \\
\text { Gehlenite } \\
\text { Pyroxenes } \\
\text { Iron Spinel } \\
\text { Leucite } \\
\text { Metallic iron }\end{array}$ \\
\hline Vilox600 & $\begin{array}{l}\text { Calcareous clay fired at } \\
600^{\circ} \mathrm{C} \text { in oxidizing } \\
\text { atmosphere }\end{array}$ & $\begin{array}{l}\text { Quartz } \\
\text { Dolomite } \\
\text { Calcite } \\
\text { Plagioclase } \\
\text { feldspar } \\
\text { Hematite }\end{array}$ & \begin{tabular}{l|} 
Clay \\
minerals \\
(illite/ \\
muscovite \\
and chlorite)
\end{tabular} & \\
\hline Vilox 850 & $\begin{array}{l}\text { Calcareous clay fired at } \\
850^{\circ} \mathrm{C} \text { in oxidizing } \\
\text { atmosphere }\end{array}$ & $\begin{array}{l}\text { Quartz } \\
\text { Plagioclase } \\
\text { feldspar } \\
\text { Hematite }\end{array}$ & $\begin{array}{l}\text { Clay } \\
\text { Minerals } \\
\text { (illite/ } \\
\text { muscovite }\end{array}$ & $\begin{array}{l}\text { Gehlenite } \\
\text { Pyroxenes }\end{array}$ \\
\hline Vilox1100 & $\begin{array}{l}\text { Calcareous clay fired at } \\
1100^{\circ} \mathrm{C} \text { in oxidizing } \\
\text { atmosphere }\end{array}$ & $\begin{array}{l}\text { Quartz } \\
\text { Plagioclase } \\
\text { feldspar } \\
\text { Hematite }\end{array}$ & & $\begin{array}{l}\text { K-feldspars } \\
\text { Gehlenite } \\
\text { Pyroxenes } \\
\text { Leucite }\end{array}$ \\
\hline Portol800 & $\begin{array}{l}\text { Non calcareous clay } \\
\text { fired at } 800^{\circ} \mathrm{C} \text { in } \\
\text { oxidizing atmosphere }\end{array}$ & $\begin{array}{l}\text { Quartz } \\
\text { K-feldspars } \\
\text { Hematite }\end{array}$ & $\begin{array}{l}\text { Clay } \\
\text { minerals } \\
\text { (illite/ } \\
\text { muscovite) }\end{array}$ & \\
\hline Portol1100 & $\begin{array}{l}\text { Non calcareous clay } \\
\text { fired at } 1100^{\circ} \mathrm{C} \text { in } \\
\text { oxidizing atmosphere }\end{array}$ & $\begin{array}{l}\text { Quartz } \\
\text { K-feldspars } \\
\text { Hematite }\end{array}$ & & $\begin{array}{l}\text { Mullite } \\
\text { Corundum }\end{array}$ \\
\hline MPY93/26 & $\begin{array}{l}\text { Coarse non calcareous } \\
\text { ceramic sherd with a } \\
\text { high Cr content }\end{array}$ & \multicolumn{3}{|c|}{$\begin{array}{l}\text { Quartz, Plagioclase feldspars, Calcite, } \\
\text { Hematite, Clay minerals (illite/muscovite) } \\
\text { Firing Temperature } 750^{\circ} \mathrm{C}\end{array}$} \\
\hline S-13 & $\begin{array}{l}\text { Fine, calcareous } \\
\text { ceramic sherd, } \\
\text { deformed (almost } \\
\text { molten) due to over } \\
\text { firing }\end{array}$ & \multicolumn{3}{|c|}{$\begin{array}{l}\text { Quartz, Plagioclase feldspars, K-feldspars, } \\
\text { Pyroxenes, Leucite, Calcite, Analcime } \\
\text { Firing Temperature } 1100^{\circ} \mathrm{C}\end{array}$} \\
\hline CS-26 & $\begin{array}{l}\text { Coarse, low calcareous } \\
\text { ceramic sherd with a } \\
\text { high } \mathrm{Zr} \text { content }\end{array}$ & \multicolumn{3}{|c|}{$\begin{array}{l}\text { Quartz, alkali-feldspars, Hematite, Clay } \\
\text { Minerals (illite-muscovite) } \\
\text { Firing Temperature } 950^{\circ} \mathrm{C}\end{array}$} \\
\hline $120-\mathrm{B}$ & $\begin{array}{l}\text { Low calcareous sherd } \\
\text { with a high monazite } \\
\text { content }\end{array}$ & \multicolumn{3}{|c|}{$\begin{array}{l}\text { Quartz, K-feldspars, Hematite, Mullite, traces } \\
\text { of illite-muscovite } \\
\text { Firing Temperature } 1000^{\circ} \mathrm{C}\end{array}$} \\
\hline GE-076 & $\begin{array}{l}\text { Low calcareous sherd } \\
\text { with a relatively high } \\
\text { Ti content }\end{array}$ & \multicolumn{3}{|c|}{$\begin{array}{l}\text { Quartz, Plagioclase, Hematite, Amphibole, } \\
\text { Clinoenstatite, Spinel, Mullite. } \\
\text { Firing Temperature } 1000^{\circ} \mathrm{C}\end{array}$} \\
\hline
\end{tabular}

Table 1.

General characteristics and mineralogical composition of the samples selected for the study. 


\begin{tabular}{|l|l|l|l|}
\hline Element & Precision (\%) & Accuracy (\%) & LDL (ppm) \\
\hline $\mathrm{Na}$ & 5.8 & 1.0 & 5. \\
\hline $\mathrm{Ca}$ & 8.0 & 9.0 & 3000 \\
\hline $\mathrm{Sc}{ }^{* *}$ & 1.8 & 1.5 & 0.01 \\
\hline $\mathrm{Cr}^{* *}$ & 2.5 & 11 & 0.80 \\
\hline $\mathrm{Fe}$ & 1.1 & 0.8 & 60.0 \\
\hline $\mathrm{Co}^{* *}$ & 1.5 & 0.8 & 0.08 \\
\hline $\mathrm{Rb}^{* *}$ & 4.0 & 4.3 & 3. \\
\hline $\mathrm{Cs}^{* *}$ & 2.4 & 8.4 & 0.20 \\
\hline $\mathrm{La}^{* *}$ & 3.5 & 8.2 & 0.04 \\
\hline $\mathrm{Ce}^{* *}$ & 2.5 & 11 & 0.50 \\
\hline $\mathrm{Sm}^{* *}$ & 5.8 & 3.2 & 0.01 \\
\hline $\mathrm{Eu}^{* *}$ & 2.9 & 0.8 & 0.03 \\
\hline $\mathrm{Tb}^{* *}$ & 9.8 & & 0.10 \\
\hline $\mathrm{Yb}^{*}$ & 5.7 & 19 & 0.06 \\
\hline $\mathrm{Lu}^{* *}$ & 5.7 & & 0.01 \\
\hline $\mathrm{Th}^{* *}$ & 1.4 & 1.7 & 0.08 \\
\hline $\mathrm{U}^{* *}$ & 7.9 & 23 & 0.20 \\
\hline
\end{tabular}

Table 2.

Precision, accuracy and lower detection limits for the analysis by Neutron Activation Analysis.

*: For these elements neither certified nor recommended values are given by NIST. **: The values of these elements given by NIST for the Montana Soil (SRM 2711) are non-certified. 


\begin{tabular}{|l|l|l|l|}
\hline Element & Precision (\%) & Accuracy (\%) & LDL (\%) \\
\hline $\mathrm{Na}_{2} \mathrm{O}^{* *}$ & 1.4 & 24 & 0.10 \\
\hline $\mathrm{MgO}$ & 2.7 & 2.0 & 0.12 \\
\hline $\mathrm{Al}_{2} \mathrm{O}_{3}$ & 0.3 & 0.6 & 0.15 \\
\hline $\mathrm{SiO}_{2}$ & 0.2 & 0.6 & 1.13 \\
\hline $\mathrm{K}_{2} \mathrm{O}$ & 0.5 & 0.2 & 0.05 \\
\hline $\mathrm{CaO}$ & 1.0 & 2.5 & 0.04 \\
\hline $\mathrm{TiO}$ & 1.7 & 5.9 & 0.01 \\
\hline $\mathrm{MnO}$ & 3.6 & 7.4 & 0.01 \\
\hline $\mathrm{Fe}_{2} \mathrm{O}_{3}$ & 0.4 & 2.1 & 0.07 \\
\hline $\mathrm{Ni}^{1}$ & 2.2 & 6.9 & 0.0005 \\
\hline $\mathrm{Sr}^{* *}$ & 2.7 & 12 & 0.002 \\
\hline $\mathrm{Rb}^{* *}$ & 4.2 & 13 & 0.005 \\
\hline $\mathrm{Zr}^{* *}$ & 2.9 & 10 & 0.004 \\
\hline $\mathrm{Ba}^{* *}$ & 3.5 & 15 & 0.01 \\
\hline $\mathrm{Th}^{* *}$ & 4.9 & 13 & 0.0003 \\
\hline
\end{tabular}

\section{Table 3}

Precision, accuracy and lower detection limits for the analysis by X-Ray Fluorescence.

${ }^{1}$ : values for accuracy and precision are affected by the low concentration of $\mathrm{Ni}$ in the reference material SRM 2711 (NIST). Therefore the accuracy and precision values for $\mathrm{Ni}$ are calculated with the use of the SRM SL-1 (IAEA certified material).

**: The values of these elements given by NIST for the Montana Soil (SRM 2711) are non-certified. 


\begin{tabular}{|c|c|c|c|c|c|c|c|c|c|c|c|c|c|c|c|c|c|c|c|c|c|c|c|c|c|c|c|}
\hline Sample & \begin{tabular}{|l|}
$\mathrm{Na}$ \\
$(\%)$
\end{tabular} & $\begin{array}{l}\text { Mg } \\
(\%)\end{array}$ & \begin{tabular}{|l}
$\mathbf{A l}$ \\
$\mathbf{( \% )}$
\end{tabular} & $\begin{array}{l}\mathbf{S i} \\
(\%)\end{array}$ & \begin{tabular}{|l}
$K$ \\
$(\%)$
\end{tabular} & $\begin{array}{l}\mathrm{Ca} \\
(\%)\end{array}$ & Sc & $\begin{array}{l}\mathbf{T i} \\
\mathbf{( \% )}\end{array}$ & $\mathrm{Cr}$ & $\begin{array}{l}\text { Mn } \\
\text { (\%) }\end{array}$ & $\begin{array}{l}\mathbf{F e} \\
(\%)\end{array}$ & Co & $\mathbf{N i}$ & $\mathbf{R b}$ & $\mathbf{S r}$ & $\mathbf{Z r}$ & Cs & Ba & La & $\mathrm{Ce}$ & Sm & $\mathbf{E u}$ & $\mathbf{T b}$ & $\mathbf{Y b}$ & $\mathbf{L u}$ & Th & $\mathbf{U}$ \\
\hline MPY93/26 & 1.35 & 5.73 & 7.90 & 24.6 & 1.2 & 2.69 & 29.0 & 0.70 & 23 & 0.14 & 7.30 & 4.7 & & 6.1 & & & 29 & & 3.2 & 33.0 & 3.64 & 1.11 & 71 & 63 & 0.32 & .52 & .00 \\
\hline S-13 & 0.54 & 1.90 & 10.1 & 20.8 & 2.9 & 12.0 & 17.0 & 0.40 & 87.6 & 0.06 & 4.20 & 78.2 & 49 & 214. & 467 & 124 & 14.8 & 528 & 38.0 & 87.9 & 6.28 & 1.31 & 0.77 & 2.44 & 0.27 & 16.3 & 6.30 \\
\hline 120-B & 14 & 0.76 & 11.0 & 30.8 & 3.6 & 0.89 & 11.0 & 0.39 & 56.6 & 0.02 & 3.45 & 1.9 & 32 & 18. & 190 & 209 & 22.5 & 975 & 35. & 275. & 14.2 & 3.71 & 1.80 & .71 & 0.31 & 52.6 & 5.20 \\
\hline CS-26 & 2.21 & 0.46 & 10.7 & 25.8 & 2.2 & 1.07 & 8.56 & 0.62 & 8.55 & 0.15 & 5.39 & 19.0 & 4.0 & 40.3 & 200 & 740 & 0.65 & 936 & 97.3 & 218. & 14.7 & 4.47 & 2.08 & 7.52 & 0.76 & 16.1 & 4.50 \\
\hline GE-076 & 17 & 0.85 & 9.11 & 31.0 & 0.9 & 3.01 & 17.1 & 1.03 & 107 & 0.05 & 3.40 & 56.5 & 41 & 42.1 & 189 & 428 & 3.65 & 296 & 52.6 & 116. & 7.59 & 1.84 & 1.11 & 4.85 & 0.55 & 16.4 & 5.90 \\
\hline Villafranca & 0.58 & 2.24 & 8.70 & 24.9 & 3.0 & 8.25 & 16.0 & 0.52 & 93.0 & 0.06 & 4.64 & 21.0 & 39 & 149 & 303 & 176 & 9.20 & 428 & 42.9 & 91.7 & 7.48 & 1.49 & 0.77 & 3.18 & 0.41 & 14.0 & 3.68 \\
\hline Portol & 0.19 & 0.90 & 11.9 & 27.1 & 3.0 & 0.47 & 22.0 & 0.70 & 149 & 0.13 & 6.40 & 34.0 & 56 & 195 & 114 & 223 & 11.0 & 451 & 66.6 & 145 & 11.1 & 2.39 & 1.60 & 5.09 & 0.59 & 20.0 & 3.39 \\
\hline
\end{tabular}

\section{Table 4.}

Chemical composition of the samples determined by Neutron Activation Analysis and X-Ray Fluorescence Spectrometry (all values are in ppm unless otherwise indicated). 



\begin{tabular}{|l|l|l|l|}
\hline Element & Precision (\%) & Accuracy (\%) & LDL (ppm in solid sample) \\
\hline $\mathrm{Na}{ }^{* *}$ & 4.8 & 4.9 & 2. \\
\hline $\mathrm{Mg}$ & 8.9 & 8.9 & 3.055 \\
\hline $\mathrm{Al}$ & 3.6 & 6.1 & 2.460 \\
\hline $\mathrm{K}$ & 2.0 & 3.9 & 13.50 \\
\hline $\mathrm{Ca}$ & 3.5 & 7.8 & 0.413 \\
\hline $\mathrm{Sc}{ }^{* *}$ & 3.4 & 12 & 0.029 \\
\hline $\mathrm{Ti}$ & 3.4 & 10 & 0.193 \\
\hline $\mathrm{Mn}$ & 4.6 & 8.5 & 0.106 \\
\hline $\mathrm{Fe}$ & 3.4 & 3.3 & 0.340 \\
\hline $\mathrm{Ni}{ }^{1}$ & 12. & 15 & 1.617 \\
\hline $\mathrm{Sr}$ & 5.7 & 4.9 & 0.009 \\
\hline $\mathrm{Ba}$ & 3.1 & 3.5 & 0.200 \\
\hline
\end{tabular}

\section{Table 5.}

Precision, accuracy and lower detection limits for the analysis by Inductively Coupled Plasma-Optical Emission Spectroscopy.

1. values for accuracy and precision are affected by the low concentration of $\mathrm{Ni}$ in the reference material SRM 2711 (NIST). Therefore the accuracy and precision values for $\mathrm{Ni}$ are calculated with the use of the SRM SL-1 (IAEA certified material).

**: The values of these elements given by NIST for the Montana Soil (SRM 2711) are non-certified. 


\begin{tabular}{|l|l|l|l|}
\hline Element & Precision (\%) & Accuracy (\%) & LDL (ppb in solid sample) \\
\hline $\mathrm{Sc}^{* *}$ & 5.1 & 23 & 214.5 \\
\hline $\mathrm{Ti}$ & 4.4 & 13 & 50.19 \\
\hline $\mathrm{Cr}{ }^{* *}$ & 7.9 & 18 & 106.9 \\
\hline $\mathrm{Mn}$ & 3.2 & 0.9 & 22.61 \\
\hline $\mathrm{Co}{ }^{* *}$ & 2.5 & 0.3 & 20.35 \\
\hline $\mathrm{Ni}^{1}$ & 5.4 & 0.5 & 25.73 \\
\hline $\mathrm{Rb}^{* *}$ & 3.1 & 4.3 & 4.350 \\
\hline $\mathrm{Sr}$ & 3.2 & 1.8 & 7.130 \\
\hline $\mathrm{Zr}{ }^{* *}$ & 64 & 20.45 \\
\hline $\mathrm{Cs}^{* *}$ & 3.3 & 22 & 15.53 \\
\hline $\mathrm{Ba}^{* * *}$ & 9.4 & 10.03 \\
\hline $\mathrm{La}^{* * *}$ & 3.0 & 3.2 & 5.160 \\
\hline $\mathrm{Ce}^{* *}$ & 10 & 5.760 \\
\hline $\mathrm{Sm}^{* *}$ & 4.8 & 1.4 & 54.36 \\
\hline $\mathrm{Eu}^{* *}$ & 3.1 & 1.2 & 17.67 \\
\hline $\mathrm{Tb}^{*}$ & 3.1 & & 18.54 \\
\hline $\mathrm{Yb}^{* *}$ & 3.1 & 3.3 & 56.02 \\
\hline $\mathrm{Lu}^{*}$ & 3.1 & & 16.23 \\
\hline $\mathrm{Th}^{* *}$ & 3.0 & 1.4 & 10.67 \\
\hline $\mathrm{U}^{* *}$ & 3.1 & 4.9 & 9.930 \\
\hline & 3.9 & & \\
\hline
\end{tabular}

\section{Table 6.}

Precision, accuracy and lower detection limits for the analysis by Inductively Coupled Plasma-Mass Spectroscopy.

${ }^{1}$ : values for accuracy and precision are affected by the low concentration of $\mathrm{Ni}$ in the reference material SRM 2711 (NIST). Therefore the accuracy and precision values for $\mathrm{Ni}$ are calculated with the use of the SRM SL-1 (IAEA certified material).

*: These elements do not have certified or recommended values.

**: The values of these elements given by NIST for the Montana Soil (SRM 2711) are non-certified 


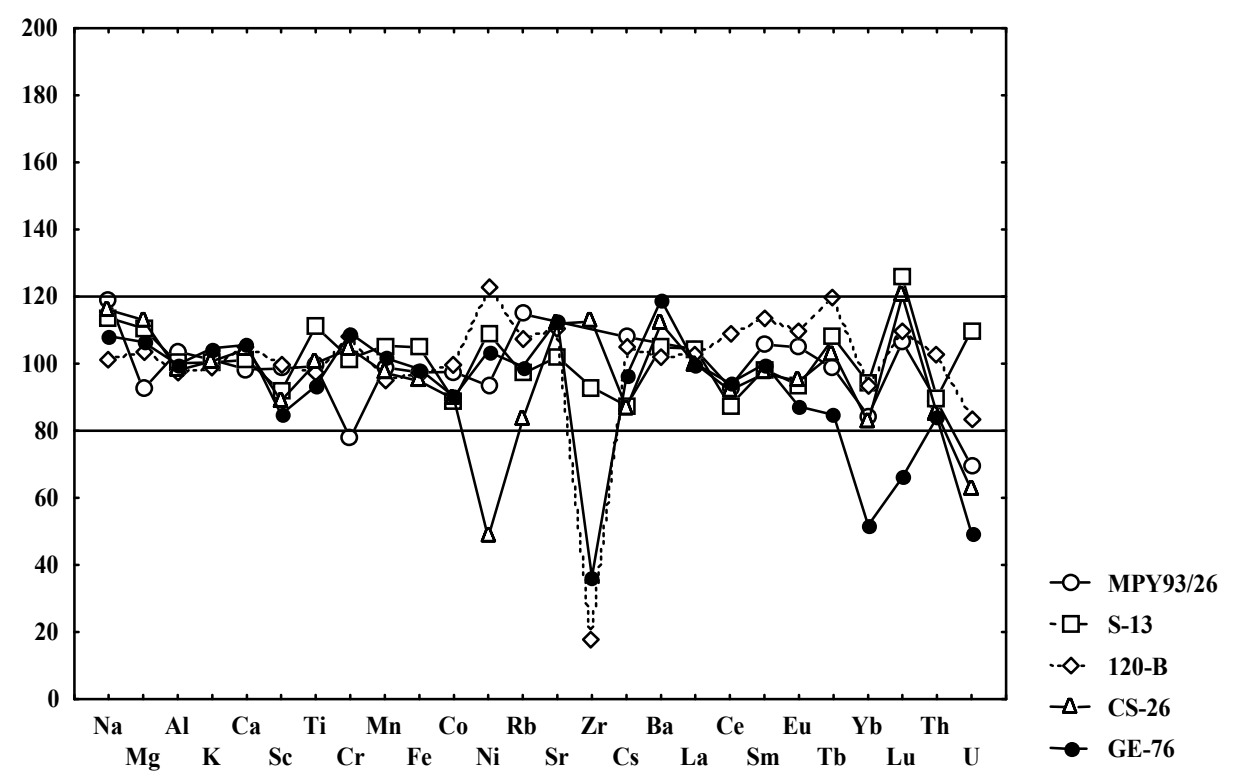

\section{Figure 1.}

Recoveries after the dissolution by acid attack in open beakers of the samples MPY93/26, S-13, 120-B, CS-26 and GE-76 


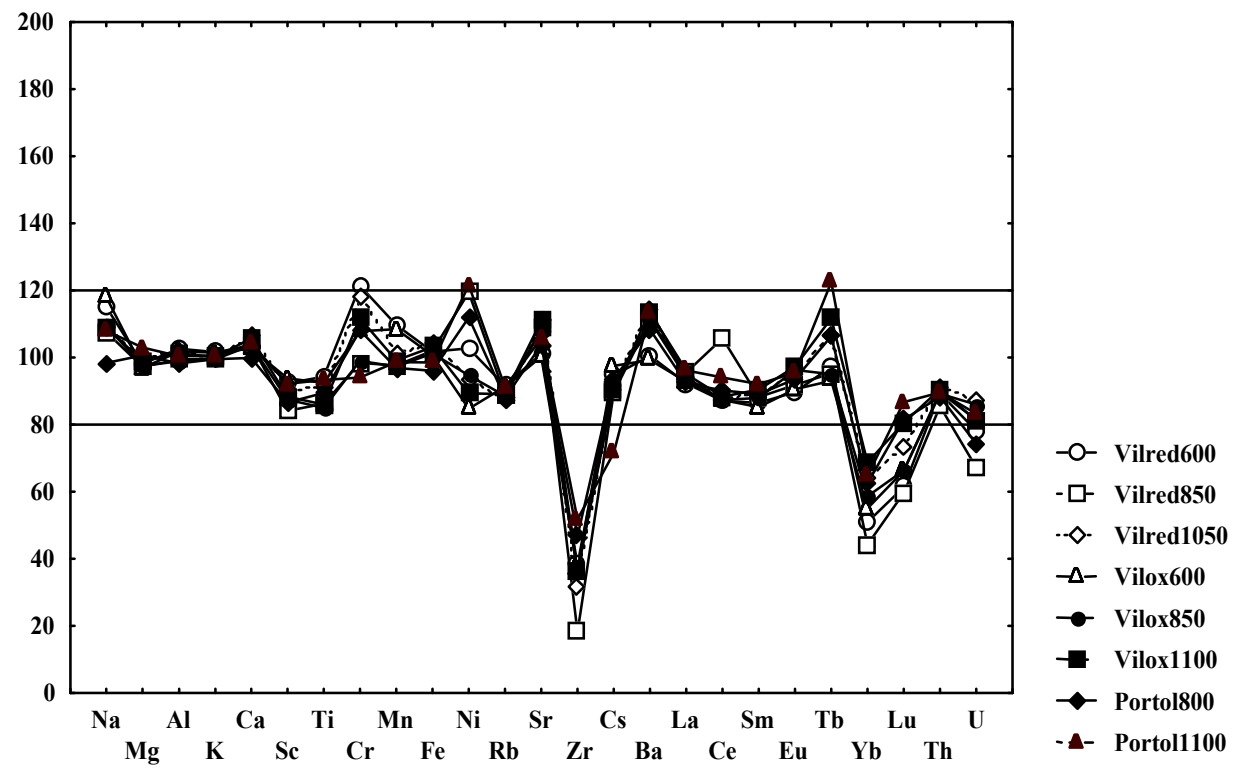

Figure 2.

Recoveries after the dissolution by acid attack in open beakers of the samples Vilred600, Vilred850, Vilred1050, Vilox600, Vilox850, Vilox1100, Porto1800 and Portol1100. 


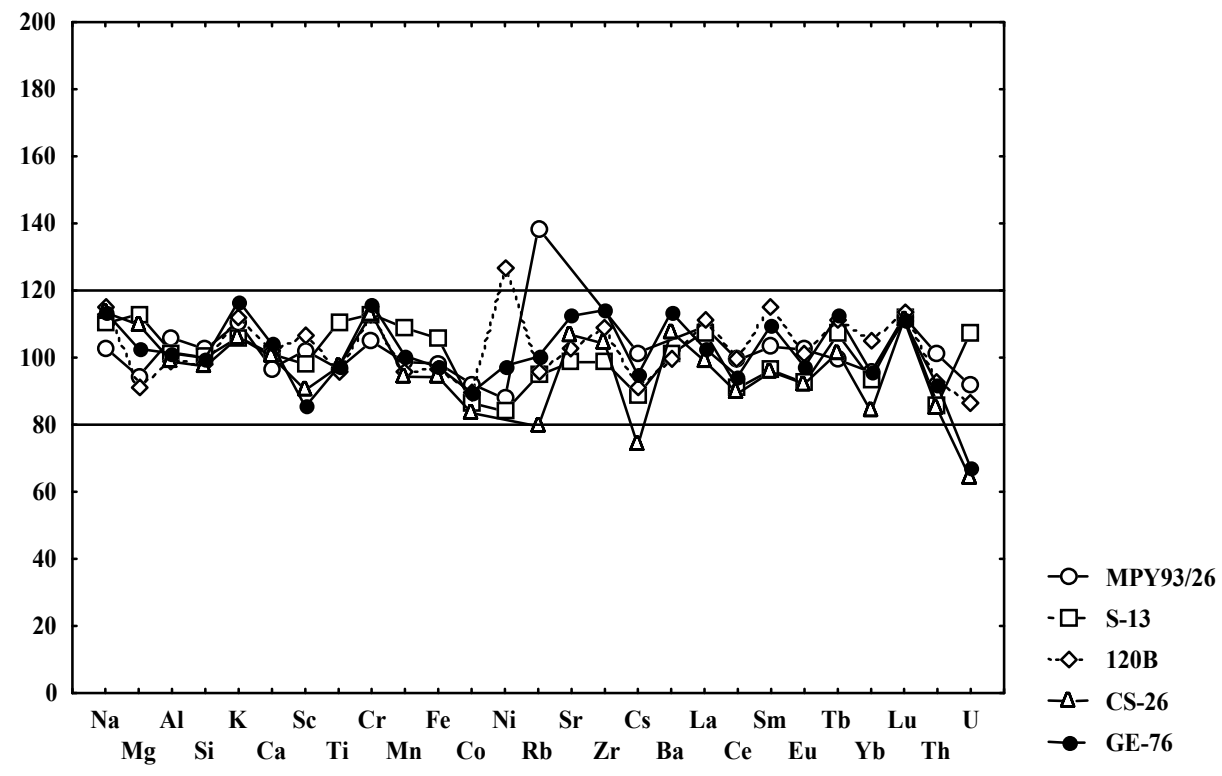

\section{Figure 3.}

Recoveries after the fusion with $\mathrm{LiBO}_{2}$ of the samples MPY93/26, S-13, 120-B, CS-

26 and GE-76 


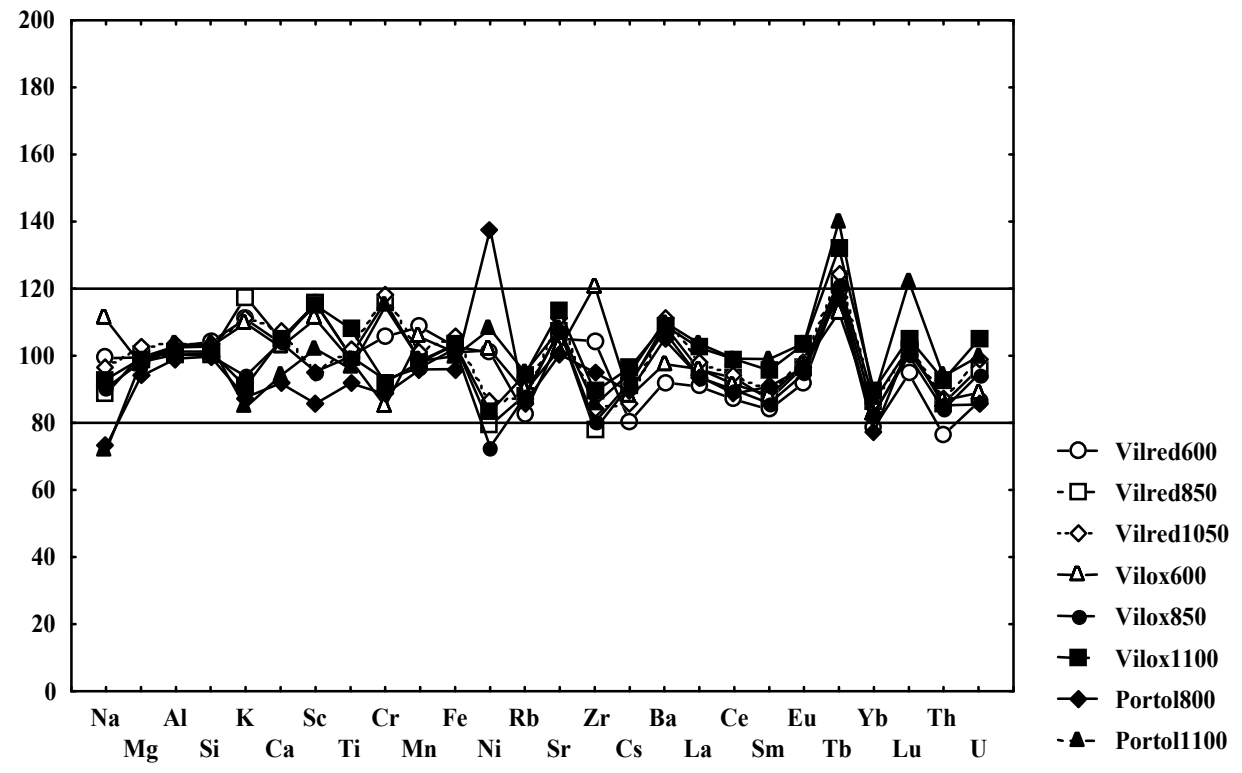

\section{Figure 4.}

Recoveries after the fusion with $\mathrm{LiBO}_{2}$ of the samples Vilre600, Vilred850,

Vilred1050, Vilox600, Vilox850, Vilox1100, Porto1800 and Portol1100. 


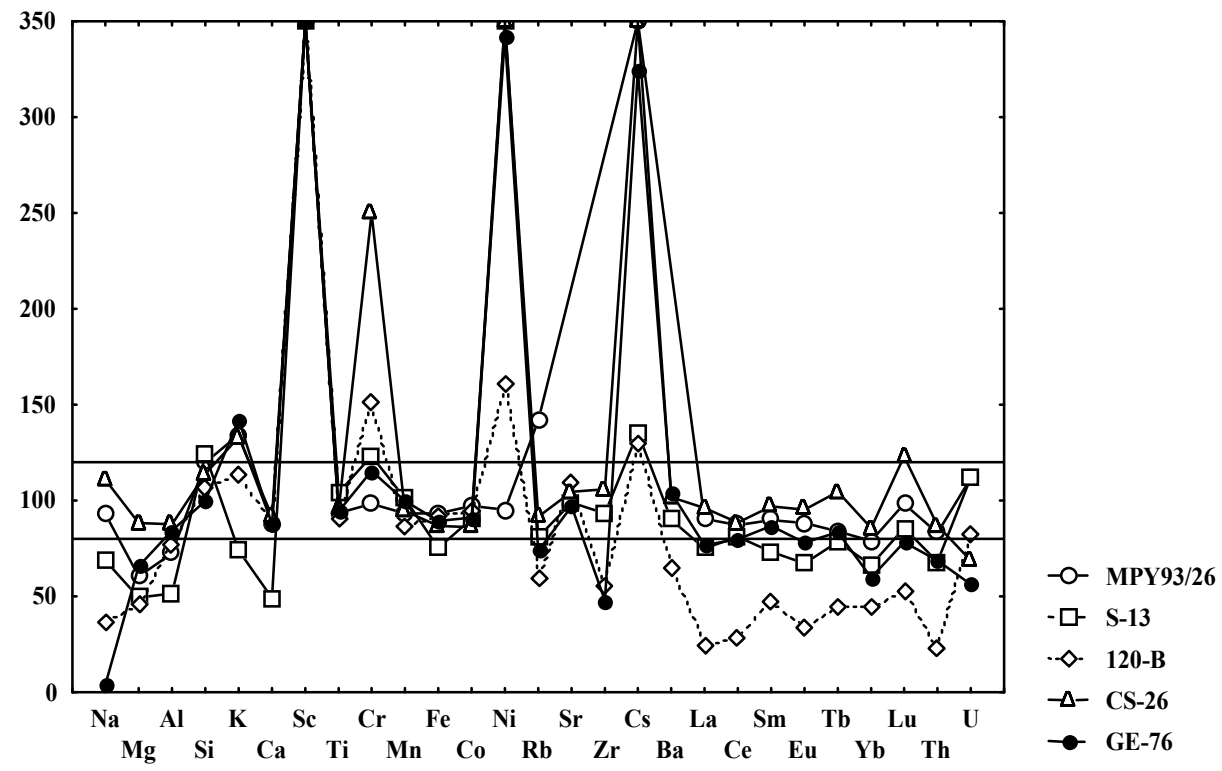

Figure 5.

Recoveries after the microwave digestion of the samples MPY93/26, S-13, 120-B, CS-26 and GE-76 


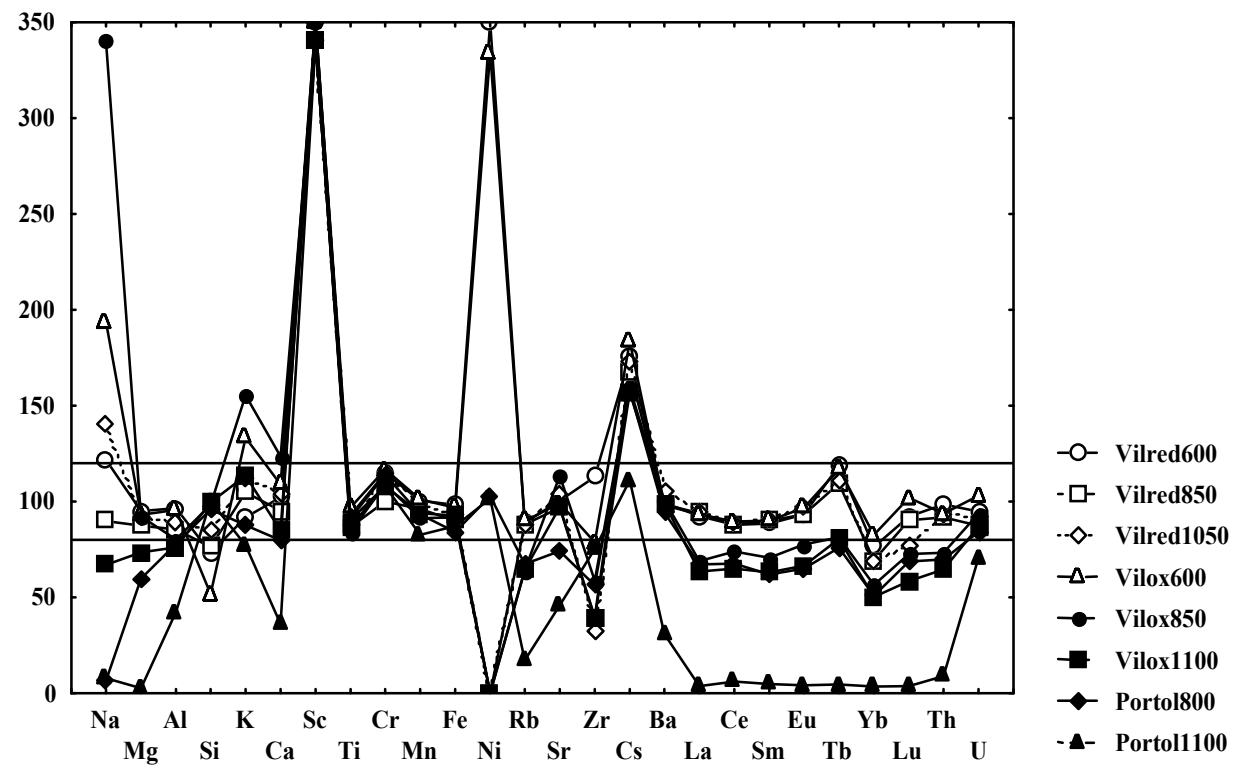

\section{Figure 6.}

Recoveries after the microwave digestion of the samples Vilred600, Vilred850,

Vilred1050, Vilox600, Vilox850, Vilox1100, Porto1800 and Portol1100. 